Izabela Buczyńska*

\title{
Odczyn popromienny u chorych na nowotwory regionu głowy i szyi w diagnozie i terapii logopedycznej
}

Radioreaction In Patients With head and neck tumours In Diagnosis And Speech Therapy

Słowa kluczowe: radioterapia chorych na nowotwory regionu głowy i szyi, odczyn popromienny, terapia logopedyczna Keywords: radiation therapy of head and neck cancer, radioreaction complications, speech therapy

\section{Wprowadzenie}

\section{Logopedia w onkologii}

Postęp w zakresie chirurgii onkologiczno-rekonstrukcyjnej obszaru twarzoczaszki, jaki obserwujemy od lat dziewięćdziesiątych XX wieku, wyznaczył nowe interdyscyplinarne podejście do diagnozy i terapii logopedycznej chorych na nowotwory regionu głowy i szyi. Opracowanie procedur niezbędnych do diagnostyki onkologopedycznej wydaje się dziś najważniejszym zadaniem merytoryczno-metodologicznym współczesnej logopedii. W związku z tym, że logopedia na stałe odnalazła swoje miejsce $\mathrm{w}$ onkologii, celem artykułu jest poszerzenie dostępnej wiedzy praktyczno-teoretycznej o diagnozę i terapię logopedyczną powikłań po radioterapii nowotworów obszaru głowy i szyi, czyli tak zwany odczyn popromienny.

\section{Epidemiologia i diagnostyka nowotworów regionu głowy i szyi (NGiSz)}

Termin nowotwory regionu głowy i szyi określa grupę nowotworów, która obejmuje obszar jamy ustnej, struktury warg, krtaniową część gardła, gruczoły ślinowe, jamę nosową, nosową część gardła oraz narząd słuchu. Dziś raki obszaru głowy i szyi

* I Klinika Radioterapii i Chemioterapii, Klinika Chirurgii Onkologicznej i Rekonstrukcyjnej, Pracownia Rehabilitacyjna, Centrum Onkologii - Instytut im. Marii Skłodowskiej-Curie Oddział w Gliwicach, ul. Armii Krajowej 15, 44-100 Gliwice, e-mail: izabela.buczynska@io.gliwice.pl. 
stanowią duży problem epidemiologiczny i kliniczny - według organizacji WHO zajmują szóste miejsce w Polsce pod względem częstości występowania. Najwyższy stopień zachorowalności na wskazaną jednostkę chorobową dotyczy populacji powyżej 55. roku życia [Kawecki, 2015].

Występowanie nowotworu w tej lokalizacji ma ścisły związek ze stylem życia oraz czynnikami zewnętrznymi. $Z$ powodu uwarunkowań anatomicznych bardzo dobrze zostały określone czynniki kancerogenne nowotworów tego regionu, do których zalicza się nikotynizm, alkoholizm oraz przewlekłe, mechaniczne drażnienie błony śluzowej jamy ustnej [Wojtukiewicz, Sierko, 2000]. W ostatnich latach wskazano na jeszcze jedną przyczynę zachorowań na raka płaskonabłonkowego, określoną mianem fenomenu epidemiologicznego. Chodzi tu o dużą grupę „młodych dorosłych", tj. osób poniżej 45. roku życia, u których wykryto wirusa brodawczaka ludzkiego (human papilloma virus - HPV). Mimo że ten typ nowotworu cechuje większe zróżnicowanie i tendencja do tworzenia przerzutów odległych, to jednak daje on lepsze rokowanie wyleczenia, ponieważ jest podatny na napromieniowanie i leczenie systemowe [Gawęcki, Szyfter, Szyfter, 2007]. Niestety, nowotwory zlokalizowane w obszarze głowy i szyi w wielu przypadkach wykrywane są bardzo późno i w wysokim stopniu zaawansowania choroby. Ponad 95\% rozpoznań histopatologicznych wskazuje na raka płaskonabłonkowego, który ma tendencję do naciekania sąsiednich struktur tkankowych twarzoczaszki [Pabiszczak i wsp., 2005].

Objawy kliniczne nowotworów regionu głowy i szyi w pierwszym stadium choroby są bardzo często pomijane i kojarzone z typowym zapaleniem jamy ustnej i/lub górnych dróg oddechowych. Wczesne stany chorobowe manifestują się najczęściej owrzodzeniami, zgrubieniami w obszarze śluzówki, dolegliwościami bólowymi samoistnymi lub w trakcie połykania i/lub mówienia [Nowosielska-Grygiel i wsp., 2017].

\section{Leczenie nowotworów regionu głowy i szyi}

Radioterapia i chirurgia są podstawowymi metodami leczenia nowotworów zlokalizowanych w obrębie głowy i szyi. W początkowym okresie choroby obie metody są równoważne i każda pozwala na uzyskanie $75-90 \%$ wyleczenia. W zaawansowanym stadium pacjent poddawany jest leczeniu skojarzonemu, które obejmuje zabieg chirurgiczny, w niektórych przypadkach poprzedzony chemioterapią. U większości chorych pooperacyjnych istnieją wskazania do uzupełniającej radioterapii: samodzielnej lub skojarzonej z chemioterapią [Jassen, 2000].

Wyboru medycznego postępowania terapeutycznego w przypadku raków regionu głowy i szyi dokonuje zespół lekarzy, którzy - na podstawie wyników badań obrazowych (tomografia komputerowa, rezonans magnetyczny, USG) i biochemicznych krwi - decydują o sposobie leczenia. Preferowane jest leczenie chirurgiczne, którego zakres zawsze uzależniony jest od lokalizacji i stopnia zaawansowania ogniska pierwotnego. W rakach o miejscowym zaawansowaniu choroby wskazana jest rekonstrukcja ubytku płatem wolnym [Kawecki, 2015]. 
Radioterapia od dawna jest podstawową metodą leczenia chorych na nowotwory obszaru głowy i szyi. Przy użyciu najnowszej aparatury medycznej do planowania, prowadzenia i kontroli leczenia pacjentowi na okolice guza lub lożę po wycięciu ogniska chorobowego podawana jest wiązka napromieniania jonizującego o wysokiej dawce. Standardowa radioterapia trwa od 6 do 8 tygodni, ponieważ napromieniowanie prowadzone jest przez 5 dni w tygodniu, we właściwych schematach postępowania radioterapeutycznego. Efekt leczniczy tej metody terapeutycznej polega na uszkodzeniu komórek nowotworowych, w tym przede wszystkim struktur sieci DNA. Stopień uszkodzenia komórki, a tym samym skuteczność leczenia, zależy od poziomu utlenienia guza oraz od jego promieniowrażliwości [Kiprian, 2015].

\section{Odczyn popromienny $\mathrm{w}$ radioterapii}

\section{Mechanizmy i konsekwencje powikłań po radioterapii nowotworów głowy i szyi}

Proces leczenia nowotworów obszaru głowy i szyi nie ogranicza się tylko do ogniska chorobowego. Promieniowanie jonizujące obejmuje swoim zasięgiem również zdrowe struktury tkankowe i narządy krytyczne, wywołując działania niepożądane. Skutkiem ubocznym radioterapii jest apoptoza komórek, czyli ich wymuszona śmierć, której obraz kliniczny został określony jako odczyn popromienny. Mechanizm powstania odczynu popromiennego polega na szybkim niszczeniu struktur DNA. Niestety, proces odbudowy jest bardzo długi i skomplikowany [Osuch-Wójcikiewicz, Bruzgielewicz, 2010]. Gwałtowny spadek liczby komórek prowadzi do zmian anatomicznych we wszystkich warstwach nabłonka. Miejscowe skutki uboczne, powstałe na obszarze błon śluzowych jamy ustnej, powierzchni skóry twarzy i szyi oraz w narządach krytycznych (wzrok, słuch), są podstawą do określenia stopnia ich uszkodzenia w trakcie i/lub po zakończeniu leczenia onkologicznego [Hutnik i wsp., 2013].

Powikłania po leczeniu radioterapeutycznym podzielone są na odczyn popromienny wczesny/ostry i późny. Odczyn popromienny w fazie wczesnej występuje w trakcie leczenia i bezpośrednio po jego zakończeniu tj. do 3-6 miesięcy. Powikłania $\mathrm{w}$ tej fazie $\mathrm{w}$ wielu przypadkach są odwracalne, ale przy zastosowaniu właściwego leczenia wspomagającego. Natomiast objawy niepożądane w tak zwanej fazie późnej trwają od 6 miesięcy do kliku lat po zakończeniu leczenia radioterapeutycznego [Składowski, 2001].

Rozległość odczynu popromiennego pozwoliła wyznaczyć jeszcze jedno kryterium podziału na odczyn miejscowy i ogólnoustrojowy. Odczyn miejscowy wczesny to rumień skóry i zapalenie błon śluzowych, a miejscowy późny to zwłóknienie tkanek mięśniowych, tworzenie się przetok w miejscach pooperacyjnych i napromienianych 
oraz popromienna martwica kości, zwłaszcza żuchwy. Powikłania ogólnoustrojowe wczesne manifestują się nudnościami, wymiotami i gorączką neutropeniczną, natomiast późne obejmują uszkodzenie szpiku kostnego ze względu na wcześniejsze deformacje struktury DNA. Skutki uboczne radioterapii zazwyczaj pojawiają się po 12-15 naświetlaniach, szczyt osiągają około 18-20, aby wycofać się pod koniec leczenia, które przypada - w zależności od przyjętego schematu postępowania terapeutycznego - na 30, 33 lub 35 dawkę frakcyjną [Ziółkowska i wsp., 2011].

Czynniki ryzyka wystąpienia odczynu popromiennego są następujące:

1) wysokość dawki całkowitej,

2) liczba dawek frakcyjnych i długość leczenia,

3) skojarzenie radioterapii z chemioterapią,

4) budowa strukturalna i anatomiczna poszczególnych narządów, zwłaszcza oporność nowotworu na radioterapię,

5) choroby współistniejące, głównie schorzenia internistyczne,

6) stan odżywienia chorego i poziom psychofizyczny.

Postępowanie radioterapeutyczne, wywołując efekt toksyczności leczenia, może prowadzić do upośledzenia funkcjonowania organizmu, niedożywienia, pogorszenia ogólnego stanu chorego, a nawet śmierci. Decyzja lekarza prowadzącego radioterapię o wdrożeniu leczenia wspomagającego (przeciwbólowego, przeciwzapalnego, celowanej antybiotykoterapii) pozwala ograniczyć ból i cierpienie oraz ustabilizować jakość życia pacjenta w trakcie i po leczeniu onkologicznym. W efekcie leczenia wspomagającego dochodzi do procesów odbudowy nowych komórek czynnościowych, a tym samym zmniejszenia poziomu bólu i obniżenia stopnia odczynu popromiennego [Ziółkowska i wsp., 2011].

\section{Odczyn popromienny w logopedii}

\section{Logopedyczna ocena odczynu popromiennego u chorych na nowotwory regionu głowy i szyi}

Choroba nowotworowa narządów głowy i szyi jest stanem przewlekłym, który zaburza sferę anatomiczną, funkcjonalną oraz psychologiczno-społeczną pacjenta. Radykalne i agresywne metody leczenia onkologicznego wydłużają okres przeżycia chorego, niestety, zwiększają liczbę powikłań i dysfunkcji w leczonym obszarze twarzoczaszki. Zaburzenia czynności prymarnych i sekundarnych są w wielu przypadkach odwracalne [Pluta-Wojciechowska, 2011], ale stopień ich remisji zależy między innymi od wczesnej interwencji onkologopedycznej. Logopedyczna ocena odczynu popromiennego, prowadzona $\mathrm{w}$ trakcie $\mathrm{i} / \mathrm{lub}$ po zakończeniu postępowania radioterapeutycznego, dotyczy poszczególnych struktur tkankowych kompleksu ustno-twarzowego. Diagnoza logopedyczna odczynu popromiennego została wyznaczona 
i podporządkowana poszczególnym jego fazom, dlatego mówimy o monitoringu logopedycznym odczynu popromiennego w fazie wczesnej i w fazie późnej. Zakres postępowania logoterapeutycznego $\mathrm{w}$ poszczególnych fazach przedstawiono $\mathrm{w}$ tabelach 1 i 2 .

Tabela 1. Monitorowanie odczynu popromiennego w fazie wczesnej

Monitoring logopedyczny odczynu popromiennego - faza wczesna

Potwierdzenie obecności odczynu popromiennego

Określenie stopnia odczynu popromiennego

Wprowadzenie terapii logopedycznej adekwatnej do stanu zdrowia i samopoczucia pacjenta

Współpraca logopedy z lekarzem radioterapeutą

Źródło: opracowanie własne.

Tabela 2. Monitorowanie odczynu popromiennego w fazie późnej

Monitoring logopedyczny odczynu popromiennego - faza późna

Długoterminowa opieka logopedyczna nad pacjentem onkologicznym NGiSz

Zapobieganie skutkom ubocznym radioterapii przez wdrożenie logoterapii właściwej dla aktualnego stanu zdrowia i samopoczucia pacjenta

Współpraca logopedy z lekarzem radioterapeutą

\section{Źródło: opracowanie własne.}

Obszary podlegające diagnozie logopedycznej obejmują: stan jamy ustnej, zakres koordynacji ruchowej stawu skroniowo-żuchwowego i zaburzenia aktu połykowego (dysfagia). Obecnie logopedyczna ocena odczynu popromiennego NGiSz oparta jest na skali medycznej CTCAE (Common Terminology Criteria Adverse Events) w zakresie: zapalenia jamy ustnej (MUM, MUF z obecnością objawów: XER - kserostomia - suchość, LIP - stan warg, LING - stan języka, CARIES - stan uzębienia), poziomu dysfagii (DYS) i poziomu bólu (BOL) (tabela 3). Według skali oceniany jest aktualny obraz kliniczny odczynu, który zostaje podporządkowany odpowiedniej gradacji stopniowej: od 1 do 5 stopnia, gdzie pierwsza wartość oznacza obecność odczynu, natomiast ostatnia zgon. Wartość pośrednia, czyli stopień 3, określa ciężkie nasilenie odczynu i konieczność włączenia farmakoterapii, a czasami wprowadzenia kilkudniowej przerwy terapeutycznej.

Monitoring logopedyczny odczynu popromiennego, prowadzony przez logopedę u pacjentów hospitalizowanych, obejmuje codzienne wizyty patronażowe i cotygodniową ocenę odczynu popromiennego w trzech wskazanych obszarach. Terapeuta, po konsultacji z lekarzem prowadzącym leczenie, wpisuje do indywidualnej Karty monitoringu odczynu popromiennego aktualny stopień powikłań. Prowadzony w ten sposób monitoring medyczno-logopedyczny pozwala na bardzo dokładne określenie czasu wystąpienia patomechanizmu i stopnia jego nasilenia. Kartę skali CTCAE nasilenia odczynu popromiennego w obszarach diagnozowanych przez logopedę przedstawiono w tabeli 3 . 
Tabela 3. Skala CTCAE dla oznaczenia nasilenia odczynu popromiennego w diagnozowanych obszarach

\begin{tabular}{|c|c|c|c|c|c|}
\hline Zdarzenie & 1 & 2 & 3 & 4 & 5 \\
\hline $\begin{array}{l}\text { Dysfagia (trudno- } \\
\text { ści w połykaniu) } \\
\text { DYS }\end{array}$ & $\begin{array}{l}\text { Obecność ob- } \\
\text { jawów, zacho- } \\
\text { wanie zdolności } \\
\text { spożywania } \\
\text { normalnej diety }\end{array}$ & \begin{tabular}{|l|} 
Obecność obja- \\
wów i zaburzeń \\
w zakresie jedze- \\
nia/przełykania \\
(np. zaburzenia \\
nawyków diete- \\
tycznych, doust- \\
ne suplementy \\
diety); wskazane \\
dożylne podanie \\
płynów $<24$ \\
godz.
\end{tabular} & \begin{tabular}{|l|} 
Obecność obja- \\
wów i ciężkich \\
zaburzeń w za- \\
kresie jedzenia/ \\
przełykania \\
(np. spożycie \\
nieodpowiedniej \\
liczby kalorii lub \\
ilości płynów); \\
wskazane \\
dożylne podanie \\
płynów, żywienie \\
przez sondę lub \\
żywienie pozaje- \\
litowe $\geq 24$ godz.
\end{tabular} & \begin{tabular}{|l|} 
Konsekwencje \\
zagrażające życiu \\
(np. niedrożność, \\
perforacja)
\end{tabular} & Zgon \\
\hline \begin{tabular}{|l|} 
Ból \\
BOL
\end{tabular} & $\begin{array}{l}\text { Łagodny ból } \\
\text { bez utrudnienia } \\
\text { funkcjonowania }\end{array}$ & $\begin{array}{l}\text { Umiarkowany } \\
\text { ból; ból lub leki } \\
\text { przeciwbólo- } \\
\text { we utrudniają } \\
\text { funkcjonowanie, } \\
\text { ale nie utrudniają } \\
\text { czynności dnia } \\
\text { codziennego }\end{array}$ & $\begin{array}{l}\text { Ciężki ból; ból } \\
\text { lub leki przeciw- } \\
\text { bólowe znacznie } \\
\text { utrudniają } \\
\text { czynności dnia } \\
\text { codziennego }\end{array}$ & Upośledzenie & - \\
\hline $\begin{array}{l}\text { Suchość jamy } \\
\text { ustnej/gruczo- } \\
\text { łów ślinowych } \\
\text { (kserostomia) } \\
\text { XER }\end{array}$ & $\begin{array}{l}\text { Obecność obja- } \\
\text { wów (suchość } \\
\text { lub gęsta ślina), } \\
\text { bez znaczących } \\
\text { zmian diety }\end{array}$ & $\begin{array}{l}\text { Obecność obja- } \\
\text { wów i znacząca } \\
\text { zmiana w zakre- } \\
\text { sie spożywania } \\
\text { pokarmów (np. } \\
\text { duża ilość wody, } \\
\text { inne środki } \\
\text { zmniejszające } \\
\text { tarcie, dieta } \\
\text { ograniczona } \\
\text { do pokarmów } \\
\text { przecieranych } \\
\text { i/lub miękkich, } \\
\text { wilgotnych) } \\
\end{array}$ & \begin{tabular}{|l|} 
Objawy \\
prowadzące \\
do niezdolności \\
do właściwego \\
odżywiania \\
doustnego; \\
wskazane \\
dożylne podanie \\
płynów, żywienie \\
przez sondę lub \\
żywienie pozaje- \\
litowe
\end{tabular} & - & - \\
\hline \begin{tabular}{|l} 
Zapalenie błony \\
śluzowej jamy \\
ustnej/gardła/ \\
krtani (badanie \\
kliniczne) \\
MUM \\
\end{tabular} & $\begin{array}{l}\text { Rumień błony } \\
\text { śluzowej }\end{array}$ & \begin{tabular}{|l|} 
Niejednolite \\
owrzodzenia lub \\
pseudobłony
\end{tabular} & $\begin{array}{l}\text { Zlewające się } \\
\text { owrzodzenia } \\
\text { lub pseudobło- } \\
\text { ny; krwawienie } \\
\text { przy niewielkim } \\
\text { urazie }\end{array}$ & $\begin{array}{l}\text { Martwica tkanek; } \\
\text { znaczne samoist- } \\
\text { ne krwawienie; } \\
\text { konsekwencje } \\
\text { zagrażające życiu }\end{array}$ & Zgon \\
\hline
\end{tabular}




\begin{tabular}{|c|c|c|c|c|c|}
\hline Zdarzenie & 1 & 2 & 3 & 4 & 5 \\
\hline $\begin{array}{l}\text { Zapalenie błony } \\
\text { śluzowej jamy } \\
\text { ustnej/gardła/ } \\
\text { krtani (czynnoś- } \\
\text { ciowe z obec- } \\
\text { nością objawów) } \\
\text { MUF }\end{array}$ & $\begin{array}{l}\text { Górny odcinek } \\
\text { przewodu pokar- } \\
\text { mowego i dróg } \\
\text { oddechowych: } \\
\text { objawy minimal- } \\
\text { ne, prawidłowa } \\
\text { dieta; minimalne } \\
\text { objawy od- } \\
\text { dechowe, ale } \\
\text { nieutrudniające } \\
\text { czynności }\end{array}$ & \begin{tabular}{|l|} 
Górny odcinek \\
przewodu \\
pokarmowego \\
i dróg oddecho- \\
wych: obecność \\
objawów, ale \\
możliwe jedzenie \\
i przełykanie; \\
w przypadku \\
diety zmodyf- \\
kowanej objawy \\
oddechowe \\
z utrudnieniem \\
funkcjonowania, \\
ale bez utrud- \\
nienia czynności \\
dnia codzien- \\
nego \\
\end{tabular} & $\begin{array}{l}\text { Górny odcinek } \\
\text { przewodu } \\
\text { pokarmowego } \\
\text { i dróg oddecho- } \\
\text { wych: obecność } \\
\text { objawów i brak } \\
\text { możliwości } \\
\text { odpowiedniego } \\
\text { odżywiania lub } \\
\text { nawadniania } \\
\text { doustnego; obja- } \\
\text { wy oddechowe } \\
\text { z utrudnieniem } \\
\text { czynności dnia } \\
\text { codziennego }\end{array}$ & $\begin{array}{l}\text { Objawy związa- } \\
\text { ne z konsekwen- } \\
\text { cjami zagrażają- } \\
\text { cymi życiu }\end{array}$ & Zgon \\
\hline LIP & Suche & $\begin{array}{l}\begin{array}{l}\text { Suche i popę- } \\
\text { kane }\end{array} \\
\end{array}$ & $\begin{array}{l}\text { Owrzodzone, } \\
\text { krwawiące }\end{array}$ & Opryszczka & Zgon \\
\hline LING & $\begin{array}{l}\text { Wygładzony, } \\
\text { podsychający }\end{array}$ & $\begin{array}{l}\text { Nalot, pęcherze, } \\
\text { pęknięcia }\end{array}$ & $\begin{array}{l}\text { Owrzodzenie, } \\
\text { zaczerwienienie }\end{array}$ & Krwawienie & Zgon \\
\hline CARIES & $\begin{array}{l}\text { 1-2 zęby próch- } \\
\text { nicze, bez zajęcia } \\
\text { korzeni }\end{array}$ & $\begin{array}{l}\text { Próchnica z za- } \\
\text { jęciem korzeni } \\
\text { zębowych }\end{array}$ & $\begin{array}{l}\text { Próchnica powi- } \\
\text { kłana zapaleniem } \\
\text { dziąseł, ropniem, } \\
\text { utratą zębów }\end{array}$ & - & - \\
\hline
\end{tabular}

Źródło: Common Terminology Criteria for Adverse Events.

Logopeda przeprowadza obiektywną ocenę odczynu popromiennego według schematu postępowania diagnostycznego. Rysunki 1-3 wskazują obszary diagnozy logopedycznej dla jamy ustnej, dysfagii i zakresu ruchomości stawu skroniowo-żuchwowego.

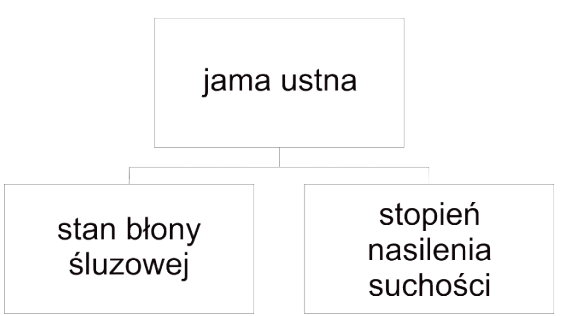

Rysunek 1. Schemat oceny logopedycznej jamy ustnej

Źródło: opracowanie własne. 


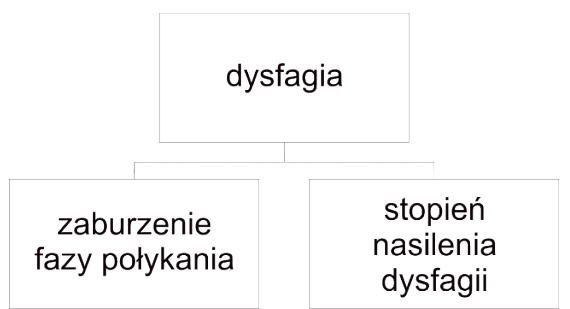

Rysunek 2. Schemat oceny logopedycznej zaburzeń połykania/dysfagii

Źródło: opracowanie własne.

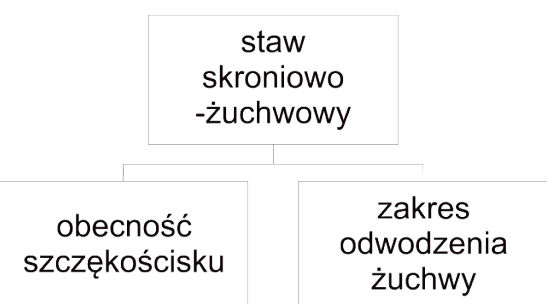

Rysunek 3. Schemat oceny logopedycznej koordynacji ruchowej stawu skroniowo-żuchwowego Źródło: opracowanie własne.

Diagnozie logopedycznej poddany jest również obraz kliniczny powikłań popromiennych, występujący w poszczególnych narządach i stanach czynnościowo-funkcjonalnych organizmu. Obraz kliniczny dla poszczególnych struktur przedstawiono w tabeli 4.

Tabela 4. Obraz kliniczny odczynu popromiennego dla poszczególnych narządów i stanów w odniesieniu do faz występowania

\begin{tabular}{|c|c|c|}
\hline Narząd & Obraz kliniczny - faza wczesna/ostra & Obraz kliniczny - faza późna \\
\hline $\begin{array}{l}\text { Błona } \\
\text { śluzowa } \\
\text { jamy } \\
\text { ustnej }\end{array}$ & $\begin{array}{l}\text { 1. Stan zapalny występuje w czterech } \\
\text { fazach ostrego odczynu popromiennego } \\
\text { śluzówkowego: faza zapalna (rumień), faza } \\
\text { nabłonkowa (epitelioliza), wrzodziejąco- } \\
\text { bakteryjna (konieczna jest farmakoterapia, aby } \\
\text { nie doszło do martwicy tkanek), faza gojenia } \\
\text { się ran. } \\
\text { 2. Zaburzenia funkcjonalno-czynnościowe } \\
\text { tego obszaru twarzoczaszki to zaburzenia } \\
\text { żucia i połykania (dysfagia) oraz suchość błon } \\
\text { śluzowych (kserostomia). } \\
\text { 3. W fazie rozlanej epiteliolizy wzrasta ryzyko } \\
\text { zakażenia bakteryjnego i grzybiczego. } \\
\text { 4. Duszność spowodowana jest obrzękiem } \\
\text { poszczególnych struktur krtani. }\end{array}$ & $\begin{array}{l}\text { 1. Zanik tkanki podskórnej. } \\
\text { 2. Włóknienie tkanek. } \\
\text { 3. Owrzodzenia i przetoki. }\end{array}$ \\
\hline
\end{tabular}




\begin{tabular}{|c|c|c|}
\hline Narząd & Obraz kliniczny - faza wczesna/ostra & Obraz kliniczny - faza późna \\
\hline Ślinianki & $\begin{array}{l}\text { 1. Najbardziej narażone na uszkodzenia są ślinianki } \\
\text { przyuszne, bo mają komórki surowicze; bardziej } \\
\text { oporne na promieniowanie są gruczoły ślinowe } \\
\text { podżuchwowe i podjęzykowe, bo zawierają } \\
\text { komórki śluzowe i surowicze. } \\
\text { 2. Występuje obrzęk, ból. } \\
\text { 3. Umiarkowana lub zaawansowana suchość } \\
\text { w jamie ustnej. } \\
\text { 4. Zaburzenia smaku. } \\
\text { 5. Lepkość i gęstość śliny. } \\
\text { 6. Dysfagia. }\end{array}$ & $\begin{array}{l}\text { 1. Przewlekła suchość w jamie } \\
\text { ustnej, tzw. kserostomia, } \\
\text { na skutek uszkodzenia } \\
\text { gruczołów ślinowych. } \\
\text { 2. Ze względu na zaburzenia } \\
\text { składu śliny próchnica } \\
\text { popromienna. }\end{array}$ \\
\hline Dysfagia & $\begin{array}{l}\text { 1. Nadwrażliwość na pokarmy kwaśne, } \\
\text { pikantne, gorące. } \\
\text { 2. Uczucie pieczenia w jamie ustnej. } \\
\text { 3. Nasilający się ból w trakcie połykania. } \\
\text { 4. Ze względu na dolegliwości bólowe } \\
\text { ograniczenie ilości przyjmowanych płynów } \\
\text { i treści pokarmowych. } \\
\text { 5. Fortyfikacja diety. } \\
\text { 6. Zmiana konsystencji diety na płynną i/lub } \\
\text { półpłynną. } \\
\text { 7. Zaburzenia smaku i/lub węchu. } \\
\text { 8. Osłabienie strukturalno-czynnościowe narządów } \\
\text { jamy ustnej i mięśni gardła. } \\
\text { 9. Szczękościsk. } \\
\text { 10. Jadłowstręt. } \\
\text { 11. Karmienie alternatywne: pozajelitowe lub } \\
\text { dojelitowe. }\end{array}$ & $\begin{array}{l}\text { 1. Utrudnione odgryzanie i żucie } \\
\text { pokarmów. } \\
\text { 2. Osłabienie strukturalno- } \\
\text { czynnościowe jamy ustnej } \\
\text { i gardła. } \\
\text { 3. Przetrwały szczękościsk. } \\
\text { 4. Stała konieczność modyfikacji } \\
\text { i fortyfikacji diety. } \\
\text { 5. Zaburzenia smaku. } \\
\text { 6. Ujemny bilans żywieniowy. } \\
\text { 7. Karmienie alternatywne: } \\
\text { dojelitowe. }\end{array}$ \\
\hline $\begin{array}{l}\text { Martwica } \\
\text { kości }\end{array}$ & - & $\begin{array}{l}\text { 1. Złamania kości żuchwy } \\
\text { ze względu na słabe ukrwienie. } \\
\text { 2. Ból, obrzęk, patologiczne } \\
\text { złamania kości szczęki i/lub } \\
\text { tworzenie się przetok. } \\
\text { 3. Próchnica popromienna. }\end{array}$ \\
\hline $\begin{array}{l}\text { Narząd } \\
\text { słuchu }\end{array}$ & $\begin{array}{l}\text { 1. Szumy uszne o charakterze ustępującym. } \\
\text { 2. Niedosłuch. }\end{array}$ & $\begin{array}{l}\text { 3. Niedosłuch w wysokich } \\
\text { częstotliwościach. } \\
\text { 4. Przetrwałe szumy uszne. }\end{array}$ \\
\hline
\end{tabular}

Źródło: opracowanie własne.

\section{Terapia logopedyczna skutków ubocznych odczynu popromiennego Przebieg postępowania terapeutycznego}

Postępowanie logopedyczne w przypadku pacjenta ze zdiagnozowanym odczynem popromiennym jest ściśle związane i dostosowane do jego aktualnego samopoczucia oraz stanu psychicznego i fizycznego. W zależności od stopnia i rozległości odczynu popromiennego logopeda we współpracy z lekarzem prowadzącym wybiera odpowiednie metody i strategie postępowania terapeutycznego. W przypadku pacjentów 
hospitalizowanych przebieg procesu terapeutycznego trwa przez cały pobyt chorego w szpitalu. Po zakończeniu leczenia w trybie szpitalnym terapia kontynuowana jest w trakcie wizyt kontrolnych.

Terapia chorych prowadzona jest indywidualnie i obejmuje:

1) rozmowę edukacyjną na temat skutków ubocznych radioterapii, występujących w trakcie trwania odczynu popromiennego i po jego ustąpieniu;

2) zapoznanie pacjenta z zestawem ćwiczeń terapeutycznych usprawniających koordynację ruchową kompleksu ustno-twarzowego oraz poszczególnych pierścieni mięśniowych odpowiadających za prawidłowe połykanie, tj.: zwarcie mięśnia okrężnego ust, zwarcie mięśniowe podniebienno-językowe i językowo-gardłowe;

3) okresową ocenę postępów terapii;

4) stałą współpracę logopedy $z$ lekarzem prowadzącym radioterapię w celu zdiagnozowania stopnia dysfagii i podjęcia interwencji żywieniowej, to znaczy włączenie żywienia pozajelitowego w przypadku wystąpienia dysfagii w stopniu 3.

Terapia logopedyczna jest obecnie integralną częścią leczenia skojarzonego chorych na nowotwory regionu głowy i szyi, ponieważ zmiany anatomiczne w obrębie twarzoczaszki powodują trudności w utrzymaniu higieny jamy ustnej, połykaniu czy koordynacji ruchowej kompleksu ustno-twarzowego. Współczesny logopeda, programując terapię logopedyczną, kieruje się przebiegiem procesu leczniczego i celami postępowania terapeutycznego.

Cele ogólne postępowania terapeutycznego:

1) łagodzenie skutków ubocznych odczynu popromiennego w fazie wczesnej/ ostrej i fazie późnej,

2) edukacja pacjenta i jego rodziny w zakresie długofalowych powikłań po leczeniu onkologicznym.

Cele szczegółowe w odniesieniu do obszarów terapii logopedycznej:

1) jama ustna:

- utrzymanie higieny jamy ustnej,

- regularne stosowanie zaleconych przez lekarza preparatów przeciwzapalnych i przeciwbakteryjnych,

- zapobieganie suchości jamy ustnej, czyli kserostomii,

2) dysfagia:

- zastosowanie ćwiczeń logopedycznych usprawniających ruchomość poszczególnych narządów jamy ustnej,

- wprowadzenie ćwiczeń miofunkcjonalnych i kompensacyjnych technik połykania,

- dostosowanie konsystencji diety do aktualnie zaburzonych faz połykania (faza oralna, gardłowa, przełykowa),

- prowadzenie bilansu spożycia płynów i produktów stałych,

- fortyfikacja diety - wzbogacenie diety o preparaty witaminowe i białkowe, 
- interwencja żywieniowa w przypadku dysfagii w stopniu 3: zastosowanie sondy odżywczej nosowo-żołądkowej, dożywiania pozajelitowego lub dożywiania dojelitowego - przezskórna gastrostomia endoskopowa (percutaneous endoscopic gastrostomy - PEG),

3) staw skroniowo-żuchwowy/szczękościsk:

- stymulacja czuciowa mięśnia żwacza, mięśnia skroniowego i skrzydłowego,

- ćwiczenia czynne i bierne stawu skroniowo-żuchwowego z zastosowaniem elementów PNF, proprioceptywne nerwowo-mięśniowe torowanie ruchu (proprioceptive neuromuscular facilitation).

\section{Zakończenie}

Zagadnienie odczynu popromiennego jak do tej pory najczęściej było analizowane w pracach medycznych. Tematyka poruszona $\mathrm{w}$ artykule dopełnia zatem wiedzę medyczną i logopedyczną [Hamerlińska-Latecka, 2015] o nowy aspekt, jakim jest diagnoza i terapia logopedyczna odczynu popromiennego u chorych na nowotwory regionu głowy i szyi.

Opracowanie wskazanego problemu badawczego pozwala na wysunięcie następujących wniosków:

1) istnieje ścisły związek między dawką promieniowania a stopniem odczynu popromiennego;

2) odnotowano korzystny wpływ terapii logopedycznej na stabilizacjęi obniżenie skutków ubocznych odczynu popromiennego u pacjentów poddanych leczeniu radioterapeutycznemu, zwłaszcza w fazie późnej;

3) monitorowanie powikłań oraz współpraca logopedy z lekarzem prowadzącym stają się ważną i integralną częścią leczenia onkologicznego;

4) wykorzystanie nowatorskiego podejścia do leczenia wspomagającego, jakim jest również terapia logopedyczna, pozwala osiągnąć wysoką skuteczność przeciwdziałania ubocznym skutkom radioterapii.

Logopedyczna diagnoza i terapia odczynu popromiennego u chorych na nowotwory regionu głowy i szyi wynika z transformacji, jakie dokonują się we współczesnej logopedii, która na stałe odnalazła swoje miejsce w onkologii. Problematyka zawarte $\mathrm{w}$ artykule stanowi wprowadzenie do szerokiego zagadnienia, jakim jest opieka logopedyczna nad pacjentem onkologicznym regionu głowy i szyi. Autorka pracy ma nadzieję, że niniejsze opracowanie pogłębi proces badawczy nad stworzeniem nowych, onkologopedycznych narzędzi diagnostycznych. 


\section{Literatura}

Common Terminology Criteria for Adverse Events, http://www.hrc.govt.nz/sites/default/files/ CTCAE\%20manual\%20-\%20DMCC.pdf (dostęp: 18.10.2018).

Gawęcki Wojciech, Szyfter Krzysztof, Szyfter Witold, 2007, Rola czynników egzogennych i epidemiologicznych $w$ etiologii raków płaskonabłonkowych głowy i szyi u młodych dorosłych, „Otolaryngologia Polska”, t. LXI, z. 1, s. 52-57.

Hamerlińka-Latecka Agnieszka, 2015, Od logopedii ogólnej do onkologopedii, [w:] taż, Onkologopedia. Logopedia wobec chorób nowotworowych, Bydgoszcz: Wydawnictwo Uniwersytetu Kazimierza Wielkiego, s. 31-46.

Hutnik Marcin i wsp., 2013, Dawki tolerancji dla narządów krytycznych w radioterapii chorych na raka głowy i szyi, „Nowotwory. Journal of Oncology”, t. 63, nr 1, s. 35-47.

Jassen Jacek, 2000, Postępy w skojarzonym leczeniu nowotworów $z$ udziałem radioterapii i chemioterapii, „Nowotwory”, t. 50, z. 1, s. 12-20.

Kawecki Andrzej, 2015, Nowotwory narządów głowy i szyi, [w:] M. Krzakowski (red.), Onkologia kliniczna, t. 2, Gdańsk: Via Medica, s. 493-522.

Kiprian Dorota, 2015, Nowoczesne techniki napromieniania w leczeniu nowotworów regionu głowy i szyi, „Polski Przegląd Otolaryngologiczny”, t. 4, z. 4, s. 1-10.

Nowosielska-Grygiel Joanna i wsp., 2016, Analiza czynników ryzyka nowotworów jamy ustnej i gardła środkowego w materiale własnym, „Otolaryngologia Polska”, t. LXXI, z. 2, s. 23-28.

Osuch-Wójcikiewicz Ewa, Bruzgielewicz Antoni, 2010, Powikłania po radioterapii nowotworów głowy i szyi, „Otolaryngologia”, t. 9, z. 1, s. 1-6.

Pabiszczak Maciej i wsp., 2005, Kierunki progresji raka jamy ustnej i gardła na podstawie analizy materiału własnego Kliniki Otolaryngologii i Onkologii Laryngologicznej AM w Poznaniu, „Otolaryngologia Polska”, t. LIX, z. 2, s. 201-207.

Pluta-Wojciechowska Danuta, 2011, Od czynności prymarnych do czynności sekundarnych, w: taż, Mowa dzieci z rozszczepem wargi i podniebienia, Kraków: Wydawnictwo Naukowe Uniwersytetu Pedagogicznego, s. 121-192.

Składowski Krzysztof, 2001, Zbadanie skuteczności i tolerancji metody ciagłego napromieniania przez 7 dni w tygodniu (CAIR) u chorego na raka jamy ustnej, gardła $i$ krtani (kontrolne badanie kliniczne), rozprawa habilitacyjna, Biblioteka Naukowa CO-I Oddział w Gliwicach, Katowice, s. 63-76.

Wojtukiewicz Marek, Sierko Ewa, 2000, Alkohol a nowotwory, „Nowotwory”, t. 50, z. 1, s. 39-47.

Ziółkowska Ewa i wsp., 2011, Odczyn popromienny u chorych na raka regionu głowy i szyi; mechanizmy i konsekwencje, „Otolaryngologia”, z. 10, nr 4, s. 147-153.

\section{Streszczenie}

Radioterapia zajmuje szczególne miejsce w leczeniu nowotworów regionu głowy i szyi. Radykalne leczenie promieniowaniem jonizującym wiąże się z wystąpieniem odczynu popromiennego. Najczęstszymi powikłaniami są: zaburzenia mowy i połykania, suchość w jamie ustnej i konieczność zmiany diety. Celem artykułu jest omówienie patogenezy, czynników ryzyka i profilaktyki odczynu popromiennego w diagnozie i terapii logopedycznej. Ćwiczenia logopedyczne, stymulacja twarzy, pielęgnacja skóry i wzbogacona dieta wpływają na zmniejszenie skutków ubocznych radioterapii. 
Summary

Radiotherapy plays a crucial role in head and neck cancers/tumours treatment. Radical treatment with ionizing radiation is associated with the occurrence of radioreaction. The most common complications in the early or late phase of the disease are: swallowing disorders, dry mouth, and a need to change the diet. The aim of this paper is to discuss pathogenesis, risk factors and radiation prophylaxis in diagnosis and speech therapy. Logopedic exercises, stimulation of facial skeleton, oral hygiene, skin care and a fortified diet help to reduce the level of complications and inhibit the side effects of radiation therapy. 